\title{
Objokovati Mnogozdraha: mit o Antigoni, pokop sovražnikov in ideal sprave v starogrški literaturi
}

Matic Kocijančič

Univerza v Ljubljani, Filozofska fakulteta, Oddelek za primerjalno književnost in literarno teorijo, Aškerčeva 2, 1000 Ljubljana https://orcid.org/0000-0003-1024-1951

matic.kocijancic@ff.uni-lj.si

\begin{abstract}
Mit o Antigoni je bil - še posebej zaradi močnega vpliva ene najpomembnejših slovenskih dram 20. stoletja, Antigone Dominika Smoleta - v Sloveniji v zadnjih petih desetletjih deležen številnih odmevnih literarnih, literarnokritiških, odrskih, filozofskih in filoloških obravnav. Bogata slovenska razprava o tem mitu je pogosto tematizirala njegovo najznamenitejšo ubeseditev, Sofoklovo Antigono, manj pozornosti pa je posvetila njegovemu širšemu antičnemu kontekstu, epskim izvirom (Iliada, Odiseja, Tebaida, Ojdipodeja) drugim tragiškim različicam (Ajshilova Sedmerica proti Tebam in izgubljeni Elevzinci, Evripidove Pribežnice, Feničanke in Antigona, od katere se je ohranilo le nekaj kratkih fragmentov) ter poznoantičnim odmevom. Članek analizira temeljne poteze te skoraj tisočletne antične tradicije in pokaže, da se na presenetljiv način povezujejo - mestoma še bolj neposredno od Sofoklove tragedije - s poglavitnima poudarkoma slovenske recepcije: vprašanjem o pokopu ubitih v (po)vojnem času in idealom sprave.
\end{abstract}

Ključne besede: starogrška književnost / literarni miti / Antigona / Homer / Ajshil / Sofokles / Evripid

Mit o Antigoni je - pod vplivom bogate literarne, gledališke, filozofske in filološke recepcije - v drugi polovici 20. stoletja postal stalna in vidna referenca slovenskega družbenega diskurza. ${ }^{1} \mathrm{~V}$ tej recepciji lahko prepoznamo številne podobnosti s predhodnimi in sočasnimi trendi interpretacije mita o Antigoni v moderni evropski kulturi, med katerimi izstopajo prevpraševanje smisla posameznikovega in kolektivnega upora, poglobljena tematizacija temeljnih eksistencialnih in ontoloških vprašanj ob motrenju Antigonine situacije, ter manj ali bolj posrečene

${ }^{1}$ Članek je nastal v okviru raziskovalnega programa št. P6-0239, ki ga je sofinancirala Javna agencija za raziskovalno dejavnost Republike Slovenije. 
primerjave spora med Antigono in Kreontom z modernimi političnimi fenomeni. Slovenska recepcija pa ima poleg teh razsežnosti tudi določene posebnosti, ki na svetovnem antigonskem zemljevidu sicer niso povsem osamljene, a vendarle odstopajo od osrednjih interpretativnih trendov. ${ }^{2}$ Med temi posebnostmi sta najbolj očitni dve. Prva je povezava mita o Antigoni s konkretnim zgodovinskim vprašanjem nepokopanih žrtev množičnih pomorov po 2 . svetovni vojni. Druga - ki se sicer navezuje na prvo, a vendarle odpira samosvoj problemski sklop je povezava tega mita s filozofskim konceptom in političnim projektom t. i. narodne sprave, ki je v drugi polovici osemdesetih in na začetku devetdesetih let 20. stoletja predstavljala eno od temeljnih osišč slovenskega kulturnega prostora. Četudi so vodilni slovenski interpreti mita o Antigoni pogosto tematizirali njegovo najznamenitejšo ubeseditev, Sofoklovo Antigono, pa so manj - izven filoloških razprav skorajda nič pozornosti posvetili njenemu širšemu antičnemu kontekstu, epskim izvirom, drugim tragiškim različicam in poznoantičnim odmevom. Kakšne so torej temeljne poteze te skoraj tisočletne antične tradicije in $\mathrm{v}$ kolikšni meri se povezujejo z osrednjima poudarkoma slovenske recepcije njenega središčnega mita?

\section{Izviri mita o Antigoni pred Sofoklom}

Nekateri ključni liki in motivi tebanskega mita se v grški literaturi prvič pojavijo že pri Homerju. Ojdipa bežno omeni 23. spev Iliade (444; 23.677-680):

Slednjič se dvigne en sam, Euríalos bógu podobni, / sin Mekistéa vladarja, mogočnemu Tálau sina, / ta je v Tebe prišél, nekoč, na pogrebno slovesnost, / kadar je padel Oidípus, prekósil tu vse je Kadmejce.

V Odiseji so obrisi mita o Ojdipu že jasnejši in prepoznavnejši (155; 11.271-280):

Videl sem tu Epikásto, Oidípoda mater prelepo, / ta je v duševni slepoti storila veliko pregreho, / zamož vdala se sinu, ko rodnega ubil je očeta, / toda bogovi kaj kmalu razkrili so zvezo pred svetom. / Vendar je v ljubljenih Tebah, trpéč bolečino in bedo, / vladal kadmejskim ljudem, po bogóv usodnem naklepu; / ona pa v zemljo je šla, k mogočnemu Hadu vratarju, /smrtno si zanko ovivši

${ }^{2}$ Za podrobnejšo analizo te recepcije glej Kocijančič, Mit o Antigoni. Prim. tudi Jensterle-Doležal. 
krog prečnega trama pod stropom, / strla je dušna jo bol: a njemu pustila je muke, / muk čez mero, kot zmeraj rodi jih matere kletev.

Tu se torej pojavi Ojdipovo incestno razmerje z materjo - pri Homerju ji je ime Epikasta, pri Sofoklu Jokasta -, vendar Homer ne omenja otrok iz tega razmerja. Se pa v Iliadi (103; 4.376-386) pojavita tudi Polinejk in Eteokles (ki ju pomemben del literarne tradicije pred atiško tragedijo opredeljuje kot sinova iz Ojdipovega naslednjega, drugega zakona):

Vsèkakor vem, da brez vojske prišèl kot gost je v Mikene, / z njim Polidéukes, božanski junak, ljudi nabiraje, / to za vojni pohòd zoper Teb posvečene zidine. / Nujno obtorej prosila od nas sta zaveznikov vrlih. / Že Mikene bilè so naréd, ustreči njih želji, / vendar je odvrnil jih Zeus in znamenja njega usodna. / Kadar nato sta odšla in pot ubiráje pod noge / travnati breg Asópa dosegla, s trstiko obrasli: / tu so poslali Ahajci Tidéa naprej na poizvedbo. / Ta res gre pa ti najde kar celo krdelo Kadmejcev, / ravno pri gôstju sedé, na domu Etéokla kneza.

Ključno pri Homerjevih bežnih tematizacijah tebanskega mita je to, da je v njih - ravno zaradi njihove bežnosti in odsotnosti pojasnjevanja mogoče razbrati predpostavko o njegovi širši prepoznavnosti, in na podlagi tega sklepati, da je mit še bistveno starejši. Obenem je razvidno, da se mit po nekaterih bistvenih potezah vidno razlikuje od najznamenitejših upodobitev v atiški tragediji: homerski Ojdip pade v vojaškem spopadu; v besedilu ni nobene informacije o njegovi slepoti ali izgnanstvu; po razkritju o incestnem razmerju še naprej vlada Tebam, kjer na koncu tudi umre (glede te pomembne razlike s Sofoklovimi prikazi je epska tradicija konsistentna, glej Cingano 221) itn.

Za našo témo je najpomembnejša razlika v tem, da se Antigona pri Homerju sploh ne pojavi. Se pa pri Homerju pojavijo - sicer ne v kakršnikoli primerljivi povezavi s Sofoklovimi umestitvami v tebansko zgodbo - drugi pomembni akterji Antigone: Tejrezias odigra vidno vlogo v Odiseji (1.11); v Iliadi sta omenjena še Hajmon (4.391-400) in Kreont (9.98), slednji tudi v Odiseji (11.269-270).

Antigona je odsotna tudi v poznejših virih do 5. stol. pr. n. št., četudi so nekatera ključna besedila o tebanskem mitu - npr. Tebaida, za katero Christiane Zimmermann spekulira, da je najverjetnejši kandidat za omembo Antigone v zgodnji epski literaturi (Zimmermann 66) - izgubljena (z izjemo maloštevilnih fragmentov in pričevanj, ki omogočajo vsaj delno rekonstrukcijo).

Tebaida je del tebanskega cikla, v katerem se je - poleg še dveh pesnitev, ki sta za našo témo manj pomembni, Epigonov in Alkmajonidenahajala tudi Ojdipodeja. Tebaida in Ojdipodeja sta imeli izjemno 
mesto v stari grški književnosti - grški geograf Pavzanias, ki je živel okoli 110-180 n. št., je Tebaido ovenčal z nazivom tretje najpomembnejše pesnitve po Iliadi in Odiseji (gl. West 42-43; Torres-Guerra 228) - in sta predstavljali glavni pisni vir tebanske mitologije v grškem svetu pred atiško tragedijo (in $s$ tem tudi glavni vir, iz katerega so tragedi črpali snov za svojo svežo reinterpretacijo te mitološke snovi; prim. Torres-Guerra 227). Gre za obsežni pesnitvi, po številu verzov skupaj primerljivi z obsegom Odiseje. Njuno avtorstvo se je pogosto pripisovalo Homerju, četudi so že antični avtorji glede tega izražali dvome. Današnji konsenz glede datiranja je, da sta mlajši od homerskih epov, pa vendar se v homerski epiki nahajajo mesta, ki kažejo na poznavanje in povzemanje Tebaide, zato raziskovalci domnevajo, da je ta pesnitev $\mathrm{v}$ ustni tradiciji živela že pred nastankom Iliade, zapisana pa je bila najverjetneje v prvi polovici 6. stol. pr. n. št. (Torres-Guerra 243). Ojdipodeja je po vsej verjetnosti prva pesnitev v tebanskem ciklu in s tem starejša od Tebaide, vendar je jasnejše datiranje njenega zapisa zaenkrat nemogoče (Cingano 214-215).

Katere vsebinske značilnosti torej lahko rekonstruiramo iz maloštevilnih fragmentov (dva fragmenta Ojdipodeje in enajst fragmentov Tebaide) in pričevanj, ki so nam na voljo? Oba ohranjena fragmenta Ojdipodeje (glej West 38-42) sta za širši kontekst antigonskega mita izjemno intrigantna in ponujata vpogled $\mathrm{v}$ izvirnost, $s$ katero je Sofokles pristopal k podedovanemu mitu. V prvem fragmentu izvemo, da je Sfinga pokončala »mogočne in majhne«, med njimi tudi "najbolj čednega in ljubeznivega, plemenitega Hajmona, sina brezgrajnega [brez-

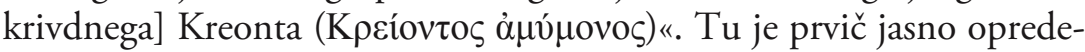
ljena sorodstvena vez med Hajmonom in Kreontom, kot jo poznamo iz Antigone, obenem pa je vsebina fragmenta povsem tuja Sofoklovi zgodbi: Kreont je označen izrazito pozitivno, kot plemenit mož brez vsakršne krivde, Hajmon pa umre kot žrtev Sfinge, ki jo je pozneje premagal Ojdip - v enem izmed sprožilnih korakov svoje osrednje tragične zgodbe -, kar seveda pomeni, da je Hajmon Ojdipodeje bistveno starejši kot pri Sofoklu (ter v poznejših variacijah Antigonine zgodbe) in obenem nima nikakršne vloge $\mathrm{v}$ bistvenih dogodkih tebanske mitologije, ki sledijo tej epizodi. S perspektive naše téme: umrl je, še preden se je rodila Antigona. ${ }^{3}$

$\mathrm{V}$ drugem fragmentu-povzetem iz Pavzanijevega pričevanjaizvemo, da Ojdip tudi v Ojdipodeji s svojo materjo Epikasto/Jokasto ni

${ }^{3}$ Walter Kaufmann v tem detajlu vidi enega izmed najzgovornejših prikazov Sofoklovega izvirnega odstopanja od mitološke predloge (Kaufmann 110). 
imel otrok, ampak je imel svoje »štiri otroke« z naslednjo ženo, Evriganejo. Iz podatka o številu otrok lahko (pogojno, kajti Pavzanias se navezuje na širše predtragiške obrise mita in Ojdipodejo uporabi le kot dokaz o pravi materi Ojdipovih otrok) sklepamo, da sta $\mathrm{v}$ tebanskem ciklu že nastopili - ali bili vsaj omenjeni - sestri Polinejka in Eteokla, četudi se $\mathrm{v}$ ohranjenih fragmentih ne pojavita. Pavzanias svoje pričevanje začne z besedami: "Ne verjamem, da je imel [Ojdip] otroke s svojo materjo", kar podkrepi z interpretacijo Homerjeve Odiseje in sklicevanjem na vsebino Ojdipodeje (9.5.10-9.5.11). Pavzanias tu torej s pomočjo starejših virov polemizira $s$ poznejšo preobrazbo mita o Ojdipu, ki je značilna za Sofoklovo tebansko trilogijo. Zakaj je bil ta poudarek za antičnega geografa tako pomemben in zakaj je bil - očitno - zanimiv tudi za grško epsko pesništvo? Po eni izmed najprepričljivejših zgodovinskih razlag gre za to, da so grške aristokratske družine svoj status pogosto utemeljevale s svojim krvnim nasledstvom herojskih rodbin iz epske mitologije, tudi po Ojdipovi liniji; odločna zavrnitev njegovega incestnega potomstva je tako imela razumljivo funkcijo pri utrjevanju te tradicije (Cingano 223). Iz obravnavanega fragmenta in njegovega zgodovinskega ozadja lahko torej izpeljemo, da je atiška tragedija - s Sofoklom na čelu - na provokativen način zaostrila incestne prvine mita o Ojdipu in s tem tudi izhodiščne pozicije tragičnih usod njegovih štirih potomcev.

Tebaida je opisovala spor med Polinejkom in Eteoklom ter nadaljnji vojaški pohod sedmerice - Polinejka in šestih argejskih junakov ( $s$ spremljevalno vojsko) - proti Tebam (s sedmimi mestnimi vrati in sedmimi branilci, na čelu z Eteoklom), v katerem so bili Argejci poraženi, brata pa sta se med seboj pobila; s tem se je izpolnilo prekletstvo, ki ga je nad njima izrekel Ojdip. Iz ohranjenih fragmentov (glej West 42-54) izvemo nekaj detajlov o ozadju Ojdipovega prekletstva njegovih sinov. Ti detajli predpostavljajo poznavanje pomembnega segmenta Ojdipove predzgodbe: mladi Ojdip je - kot vemo iz širše tebanske mitologije na poti $\mathrm{v}$ Tebe $\mathrm{v}$ cestnem prepiru ubil neznanca, za katerega je pozneje izvedel, da je bil njegov oče in prejšnji kralj Teb, Lajos; s tem se je izpolnil prvi del prerokbe, da bo Ojdip ubil svojega očeta in se poročil s svojo materjo. ${ }^{4} \mathrm{~V}$ enem izmed fragmentov Tebaide Polinejk očetu

${ }^{4}$ Glede tega, s čim si je Lajos zaslužil to prekletstvo, se antični viri razlikujejo: predsofoklovski - npr. Pindar (2. olimpijska oda, vv. 39-42; glej Pindar, Slavospevi 24-32; prim. tudi Pindar, "II. olimpijska oda«) - omenjajo predvsem njegovo neposlušnost Apolonovemu oraklju; tragiški - na čelu z Evripidom (izgubljena drama Hrizip) - in poznejši teksti pa njegovim prestopkom dodajajo še posilstvo Hrizipa, enega izmed Pelopsovih sinov (Pelops je molil k Zeusu, naj kaznuje Laja, in bil uslišan $s$ posredovanjem Apolona). Nekateri raziskovalci menijo, da je bilo posilstvo tudi $v$ 
postreže z mizo in čašo, ki sta pripadali kralju Laju, v čemer Ojdip prepozna sinovo obujanje spomina na očetomor in poskus krhanja njegove avtoritete. $\mathrm{V}$ tem fragmentu nad sinova kliče prekletstvo, naj njegove dediščine ne razdelita sporazumno, temveč naj bo ta vzrok njunega nenehnega spora in bojevanja. V drugem fragmentu izvemo, da sta Eteokles in Polinejk - skladno z običajem - očetu ob vsakem žrtvenem zakolu poslala obredno predpisani kos živali; tokrat sta mu poslala neustrezen, slabši kos. Razlage, zakaj je to vznemirilo Ojdipa, se razlikujejo - nekateri raziskovalci v tem vidijo preprosto posmehljivo kršitev dolžnosti in s tem nadaljevanje krhanja očetove/kraljeve avtoritete, drugi - v simetriji s prejšnjim fragmentom - tudi simbolni namig na Ojdipov incest (Torres-Guerra 231). Kakorkoli že, Ojdip ob tem nečastnem darilu radikalno zaostri svoje prekletstvo ter moli k Zeusu, naj njegova sinova umreta v vzajemnem poboju.

Preostali ohranjeni fragmenti se sicer ne navezujejo na motive, ki so posebej relevantni za razvoj Antigonine predzgodbe, se pa $\mathrm{v}$ sekundarnih pričevanjih o pripovednem loku Tebaide pojavi izjemno pomembna povezava z našo témo: Adrast, argoški kralj, ki mu je uspelo pobegniti iz spopada sedmeric, po bitki izrazi željo, da bi pokopal svoje padle soborce; Tebanci njegovi prošnji ustrežejo (Torres-Guerra 227). $\mathrm{V}$ navezavi na to epizodo sekundarni viri Adrastu pripisujejo izvrstne govorniške spretnosti (237). V predtragiškem mitu o spopadu med Eteoklom in Polinejkom tako že najdemo porajanje vprašanja o nepokopanih napadalcih Teb, ki pa se v Tebaidi razreši brez konfliktnega zapleta, ob čemer se glavnemu akterju tega dogovora pripisujejo osebne odlike (poznejša tradicija, npr. Ajshil, osrednjo vlogo pri tej razrešitvi pripiše Tezeju; glej Sommerstein 470).

Tudi na teh ključnih mestih v razvoju tebanskega mita še vedno nimamo nobenega ohranjenega vira za lik Antigone. Ob tem je še posebej vznemirljivo, da se njena sestra v Sofoklovem delu, Ismena, kot junakinja grške literature pojavi že v 7. stol. pr. n. št., pri pesniku Mimnermu (Allen 133-144). Ismena tu sicer ni eksplicitno sorodstveno povezana s tebansko kraljevo družino, nastopi pa v kontekstu

starejših različicah mita prvotni vzrok za prekletstvo (Lloyd-Jones 120). V vsakem primeru stojijo Lajevi prestopki na začetku tragične usode njegove rodbine (Kyriakou 45-48). Motiv Lajevega posilstva Hrizipa je bil morda prisoten tudi v Ajshilovi izgubljeni tragediji Lajos (Kovacs 367). Kovacs spekulira, da Sofokles v svoji trilogiji tega ozadja ni obnavljal zato, ker je bilo v tem času že splošno znano (Kovacs 367; prim. tudi Lamari 264). Thomas K. Hubbard v Evripidovi obravnavi Lajevega posilstva (kot izvora prekletstva nad njegovo rodbino) - ki ga v nasprotju z Lloyd-Jonesom razlaga kot tragedovo invencijo - prepoznava znak sprememb v atenski seksualni kulturi ob koncu 5. stol. pr. n. št. (Hubbard). 
spopada za Tebe. Gre za ljubezensko zgodbo med njo in enim izmed tebanskih borcev, ki se konča z njenim umorom. Zgodnja grška literatura tako Ismeno poveže $\mathrm{z}$ motivom mladostnega ljubezenskega razmerja, ki vodi v smrt, v čemer Zimmermann prepoznava enega od (manjših) predodmevov antigonskega mita (Zimmermann 70). V tem lahko uzremo nadaljevanje in utrjevanje spekulativnega okvira za domnevo, da je Sofokles - pri katerem je Ismena stranski lik brez izrazito tragične usode $-\mathrm{v}$ svojem snovanju karakterja, motivacije in usode Antigone premestil, spojil in zaostril nekatere prvine sekundarnih likov in motivov epske tebanske dediščine. Obenem se - kot pri Hajmonu tudi pri predsofoklovski Ismeni ponovno potrdi, da so pri Sofoklovem opisovanju dogodkov po napadu sedmerice nastopili (in torej preživeli) liki, ki so v starejših upodobitvah tega mita umrli pred/med spopadom ali celo bistveno prej.

Dotaknili se bomo še enega predtragiškega vira, ki je pomenljiv za našo témo. Tebanski mit se pojavi pri pesniku Stezihorju (630-555 pr. n. št.), v neimenovani pesnitvi, ki jo filološka recepcija (prav tako) imenuje Tebaida. V njej ima pomembno vlogo lik Eteoklove in Polinejkove matere, kraljice Teb. Ni sicer povsem jasno, ali gre za Jokasto/Epikasto ali Odjipovo drugo ženo (razlagalci se v luči prej opisanih zgodovinskih razlogov nagibajo $\mathrm{k}$ slednji), vendar pa je njena vloga $\mathrm{v}$ vsakem primeru bolj izrazita kot v preteklih upodobitvah mater(e) Ojdipovih otrok; Stezihorjeva kraljica namreč odločno posreduje v začetnih fazah spora med sinovoma in poskuša (brez uspeha) med njima doseči spravo (Finglass 90-91).

Tu se torej v okviru spora med Polinejkom in Eteoklom prvič pojavi ženski lik z močno sorodstveno vezjo, ki ob porajanju smrtonosnega družinskega in državnega - konflikta zastopa vrednote ljubezni in sprave (Zimmermann 76), v čemer je seveda (skladno s prej orisanim spekulativnim okvirom) mogoče prepoznati še en predtragiški motiv, ki je našel svoje mesto $\mathrm{v}$ Sofoklovi strnitvi in preobrazbi mita: tako $\mathrm{v}$ kontekstu Antigoninega (prav tako neuspešnega) spravnega poskusa v Ojdipu v Kolonu kot tudi v dihotomiji ljubezen-sovrastvo, prepoznavni razsežnosti Sofoklove Antigone. V Stezihorjevem liku kraljice, ki v svojem govoru implicitno razkriva, da ji je rešitev sinov pomembnejša od usode polisa, pa se obenem skriva tudi predodmev tragiških tematizacij

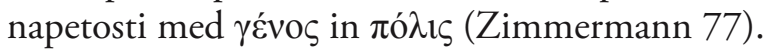

$\mathrm{V}$ tragiškem korpusu pred Sofoklom je prvi pomemben mejnik v razvoju antigonskih prvin tebanskega mita Ajshilova izgubljena tragedija Eleusinioi (Elevzinci, pribl. 475 pr. n. št.), o kateri - po zaslugi Plutarhovega Tezejevega življenja (67-69) - vemo, da gre za najzgodnejšo 
znano zastavitev vprašanja o nepokopanih napadalcih Teb z eksplicitno obravnavo spora o njihovem pokopu. Pri njegovi razrešitvi odigra ključno vlogo Tezej, mitski ustanovitelj Aten, ki se prav tako kot prej Adrast - ki tu Tezeja prosi za pomoč - izkaže z miroljubnim, diplomatskim pristopom. Plutarh dodaja podatek, da so bila pridobljena trupla zato pokopana na atiških tleh (69). V tem razvoju mita in v vlogi, ki jo v njem pridobi Tezej, vodilni atenski junak, lahko že razbiramo močno povezavo med vprašanjem pokopa vojnih sovražnikov in atiško kulturno identiteto.

Ohranjeni fragment tragedije skriva namig, da je poseben problem v sporu predstavljalo eno izmed trupel - »zadeva je bila neodložljiva, truplo je že trohnelo« (Aeschylus, Volume III. Fragments 56-57) -, vendar nimamo nobenega dokaza za to, da je šlo za Polinejka (Zimmermann 85). Tudi tu ni nobene (ohranjene) omembe Antigone niti Ismene. Obenem je ključna razlika s Sofoklovo tematizacijo v tem, da se vprašanje nepokopanih v Elevzincih očitno odvija in razrešuje primarno na politični, četudi meddržavni ravni, ne ob vprašanju religiozne ali družinske dolžnosti: mrtvi tu primarno pripadajo polisu (Zimmermann 87).

\section{Sofoklova Antigona v perspektivi širšega tragiškega korpusa}

Antigona se torej poimensko prvič pojavi šele v 5. stol. pr. n. št., a prvo omembo najdemo že pred Sofoklom, v fragmentu mitografa Ferekida iz Lerosa/Aten (prim. Cairns 9; Zimmermann 89). Ferekid poimenuje vse štiri Ojdipove otroke, njihova mati pa je tu še vedno Evriganeja, druga Ojdipova žena. Kot smo videli v pregledu razvoja tebanskega mita, je starogrška literatura pred Sofoklom tudi že izrisala nekatere temeljne motive, na katerih sloni njegova upodobitev Antigone: vprašanje pokopa padlih sovražnikov, vidna vloga spravne figure, napetost med družinsko in državno dolžnostjo. Vseeno pa se večina raziskovalcev strinja, da je osrednja dramska zamisel Sofoklove Antigone - z vsemi temeljnimi duhovnimi in političnimi posledicami, ki so fascinirale moderno misel in umetnost - izrazito izvirna: konflikt med Antigono in Kreontom se pred Sofoklom ne pojavi, v nobenem predhodnem viru ne srečamo podobnega spora. Izjemnost te tragedije je prepoznala tudi Sofoklova sodobnost, z njo si je utrdil status tragiškega velikana, po tradicionalnih biografskih prikazih pa naj bi na podlagi njene slave celo dobil funkcijo generala. ${ }^{5}$ Kljub temu je bila idejna srž Sofoklove Antigone očitno provokativna že za njegove sodobnike in neposredne naslednike.

\footnotetext{
${ }^{5} \mathrm{O}$ zadržkih glede te teze glej Scodel 30-31.
} 


\section{Zaključek Ajshilove Sedmerice proti Tebam}

Ajshilova Sedmerica proti Tebam (467 pr. n. št.), ki opisuje tebanski spopad in njegovo ozadje - predvsem z Eteoklove perspektive -, se zaključi v slogu Sofoklove Antigone, a z nekaterimi pomembnimi razlikami: pokopa Polinejka ne prepove samodržec, temveč gre za brezosebni, izglasovani državni odlok, ki ga naznani glasnik, Antigonini odločitvi za nepokorščino pa sledi razcep zbora - prva polovica se ji pridruži, druga polovica gre skupaj z Ismeno za Eteoklovim pogrebom. Nekateri raziskovalci (npr. Miola 239-240) v tem razcepu razbirajo mnenjski razkol zbora glede Antigonine pozicije, čeprav bi lahko to delitev razumeli tudi na manj konflikten način. Zbor namreč ob tej dramaturški rešitvi proporcionalno prisostvuje pri obeh pogrebih obrazložitvi odločitev obeh polzborov se pravzaprav ne izpodbijata,$- s$ čimer pisec tega zaključka morda le (nekoliko previdno) izrazi, da si oba brata zaslužita pokop, ne glede na svoje krivde in zasluge.

Sedmerica proti Tebam je seveda starejša od Antigone, orisani zaključek pa je - kot meni večina sodobnih raziskovalcev - najverjetneje psevdoajshilovski in je bil tragediji dodan približno petdeset let po njenem nastanku, kot posledica priljubljenosti Sofoklove Antigone. Ajshilovo delo naj bi se izvirno zaključilo brez problematizacije Polinejkovega pokopa, s skupnim žalovanjem zbora za obema bratoma. Problematični zaključek Sedmerice kljub vsemu - ne glede na avtorstvo in točno datiranje - razkriva pomembne vidike atiškega razumevanja antigonskega mita, na katere sem že opozoril ob interpretaciji Sofoklove Antigone (Kocijančič, »'Nič drugega kot nič' «), obenem pa, kot bistroumno pripomni Miola, predstavlja (v primeru, da je prevladujoče mnenje o datiranju ustrezno) tudi njeno prvo literarno reinterpretacijo (Miola 239), torej začetek nenavadno bogate literarne tradicije, ki jo lahko zasledujemo od antike do 21. stoletja.

Evripid je tebansko mitologijo obravnaval v treh delih: v Pribežnicah (423 pr. n. št.), Feničankah (ok. 408 pr. n. št.) in (skoraj povsem izgubljeni) Antigoni (412-406 pr. n. št.). Ta dela, ki tvorijo zadnje veliko poglavje $\mathrm{v}$ atiški transformaciji tebanskega mita, predstavljajo tudi neizčrpen laboratorij za seciranje Sofoklove inventivne zapuščine, ker po eni strani uporabljajo prepoznavne (hiper)sofoklovske strategije za osvežitev in reapropriacijo mita - liki, ki so jih prejšnje različice na posameznih stopnjah mita že pokopale, preživijo bistveno dlje (ali umrejo bistveno prej, kot v primeru Evridike v Feničankah) in s tem omogočijo manevrski prostor za nove odnose in zaplete; prepoznavni motivi epske, lirične in tragiške dediščine se nizajo in spajajo v nepred- 
vidljivih reinkarnacijah; divji karakterni preobrati mitoloških junakov vdahnejo svež pomen podedovanim situacijam -, po drugi strani pa je osrednja snov, ki jo Evripid po tem ključu suka (in se ji na številnih mestih tudi zoperstavi), prav Sofoklova.

Ti postopki so morda najbolj očitni v Feničankah. Že prvi prizor skriva veliko presenečenje: Jokasta, ki v preteklih različicah mita (od Homerja do Sofokla) naredi samomor ob razkritju, da je Ojdip njen sin in morilec svojega očeta, nas tu - živa - vpelje v dogajanje tik pred napadom sedmerice in tudi med njim odigra vidno vlogo, v kateri lahko prepoznamo Evripidovo priredbo starejše tradicije upodabljanja matere Ojdipovih otrok kot nosilke prizadevanja za spravo med sprtima sinovoma (prim. razdelek o Stezihorju zgoraj). Evripid kljub temu upošteva Sofoklovo premestitev tega motiva in spravno figuro podvoji: Jokasti se v mirovniških poskusih pridruži Antigona. Poskusi pomiritve so neuspešni tudi pri Evripidu, skupna smrt Eteokla in Polinejka je podobna kot v prejšnjih upodobitvah. Pa vendar se predzgodba (in nadaljevanje) njunega smrtnega spopada radikalno razlikujeta od prejšnjih upodobitev, pri čemer se zdi, da Evripida še posebej navdihuje preobračanje predpostavk tragiških predhodnikov.

Ajshil je v Sedmerici proti Tebam namenil osrednjo pozornost Eteoklu (Polinejk v drami sploh ne pride do besede), branitelju Teb, ki je, kot zapiše Kajetan Gantar, "pri tem prikazan v panegiričnih potezah kot pogumen in brezgrajen junak, kot heroj, ki ves izgoreva $\mathrm{v}$ domoljubju, vse njegove misli in dejanja so usmerjene $\mathrm{k}$ rešitvi in osvoboditvi domovine" (Gantar 12) pred sovražno vojsko izdajalca Polinejka. Vrednotenje bratskih značajev in motivacij se v zaključnih prizorih Ajshilove drame vendarle - in glede na Eteoklovo siceršnje mesto v drami nekoliko presenetljivo - uravnoteži: zbor nam ob smrti

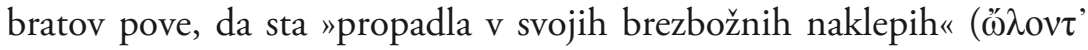

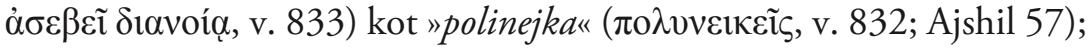

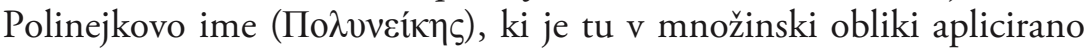
na oba brata, sestavljata pridevnik $\pi 0 \lambda u ́ \varsigma$ (mnog, številen) in samostal-

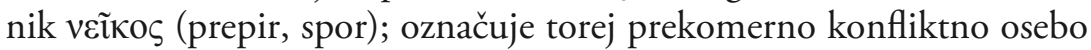
(Alojz Rebula sloveni Polinejka kot "netilca razdora«, prim. Ajshil 57; Kajetan Gantar ponudi še alternativi "Mnogozdrah" in "Zdrahar", prim. Gantar 11-13). Ajshil s tem skupnim poimenovanjem zamaje pomenski naboj Eteoklovega imena, ki ga sestavljata pridevnik غ̇ंદós

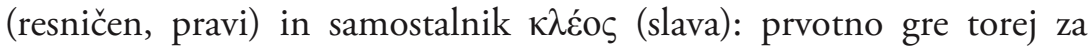
"junaka, ki pooseblja resnično slavo (Gantar 11) oziroma "upravičeno slavljenega" (Bacon in Hecht 14). Vendar Ajshil z Eteoklovim preimenovanjem ne rehabilitira Polinejka; njuno uravnoteženje poteka 
predvsem v smeri relativizacije Eteoklovega junaškega statusa, v smeri razkritja skupne krivde.

Helen H. Bacon in Anthony Hecht, ki ta preobrat in njegove etimološke razsežnosti postavljata $\mathrm{v}$ središče svoje interpretacije in prevoda Sedmerice, opozarjata na možnost alternativne etimologije Eteoklovega

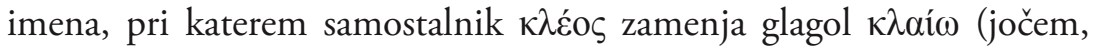
objokujem, žalujem). Takšno branje zagovarjata z dejstvom, da Eteokles $\mathrm{v}$ uvodnem nagovoru Ajshilove tragedije svoje ime prvič izreče ob sva-

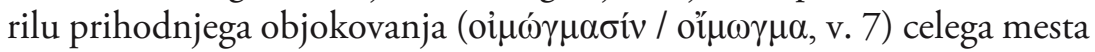
(»nešteto ust [bo] po mestu / tožilo in pomilovalo / samo Eteokla«). Kljub tej privlačni filološki domnevi - ki jo prevajalca v skladu s svojo interpretacijo nekoliko tendenciozno umestita v prevod, pri čemer Eteokla iz "upravičeno slavljenega» (justly famed) ne preimenujeta le $\mathrm{v}$ »resnično objokovanega" (truly bewept), temveč tudi v "pravi vzrok objokovanja» (true cause of weeping) - se njuna končna ocena Ajshilovega vrednotenja razmerja med bratoma vendarle ne razlikuje bistveno od Gantarjeve. Ob koncu tragedije postane jasno, da sta "usodi in imena bratov izmenljiva (interchangeable)«: oba sta "mnogozdraha«, povzročitelja konflikta in $s$ tem oba "vzrok objokovanja" ter nenazadnje $-s$ spornim psevdoajshilovskim zaključkom ali brez njega - oba vredna in deležna »resničnega objokovanja» (Bacon in Hecht 14-15).

\section{LITERATURA}

Aeschylus. Volume III. Fragments (Loeb Classical Library L505). Ur. in prev. A. H. Sommerstein. Cambridge, MA: Harvard University Press, 2008.

Aeschylus. Seven Against Thebes. Prev. Anthony Hecht in Helen H. Bacon. New York, NY; Oxford: Oxford University Press, 1973.

Ajshil. Sedmerica proti Tebam. Prev. Alojz Rebula. Maribor: Študentska založba Litera, 2005.

Allen, Archibald, ur. The Fragments of Mimnermus. Text and Commentary. Stuttgart: Franz Steiner Verlag, 1993.

Bacon, Helen H., in Anthony Hecht. "Introduction«. Seven Against Thebes. Aeschylus. Prev. Anthony Hecht in Helen H. Bacon. New York, NY; Oxford: Oxford University Press, 1973. 3-17.

Cairns, Douglas. Sophocles: Antigone. London: Bloomsbury, 2016.

Cingano, Ettore. "Oedipodea". The Greek Epic Cycle and its Ancient Reception. Ur. Marco Fantuzzi in Christos Tsagalis. Cambridge: Cambridge University Press, 2015. 213-225.

Jensterle-Doležal, Alenka. Mit o Antigoni v zahodno- in južnoslovanskih dramatikah sredi 20. stoletja. Ljubljana: Slovenska matica, 2004.

Finglass, Patrick J. "Stesichorus, master of narrative«. Stesichorus in Context. Ur. Patrick J. Finglass in Adrian Kelly. Cambridge: Cambridge University Press, 2015. 83-97. 
Gantar, Kajetan. «Ajshil in njegova 'drama polna Aresa'«. Sedmerica proti Tebam. Ajshil. Prev. Alojz Rebula. Maribor: Študentska založba Litera, 2005. 5-17.

Homer. Iliada. Prev. Anton Sovrè. Ljubljana: Državna založba Slovenije, 1950.

Homer. Odiseja. Prev. Anton Sovrè. Ljubljana: ZSK, Založba Mihelač, 1991.

Hubbard, Thomas K. »History's First Child Molester: Euripides' Chrysippus and the Marginalization of Pederasty in Athenian Democratic Discourse". Bulletin of the Institute of Classical Studies 78 (2006): 223-244.

Kaufmann, Walter. Tragedy and Philosophy. Princeton, NJ: Princeton University Press, 1992.

Kocijančič, Matic. Mit o Antigoni v povojni slovenski književnosti, fllozofiji in družbenopolitičnem diskurzu. Doktorska disertacija. Ljubljana: Univerza v Ljubljani, Filozofska fakulteta, 2020.

Kocijančič, Matic. »'Nič drugega kot nič': negativna teopolitika Sofoklove Antigone». Primerjalna književnost 44.1 (2021): 107-127.

Kovacs, David. "The Role of Apollo in Oedipus Tyrannus". The Play of Texts and Fragments. Ur. J. R. C. Cousland in James R. Hume. Leiden: Brill, 2009. 357-368.

Kyriakou, Poulheria. The Past in Aeschylus and Sophocles. Berlin: de Gruyter, 2011.

Lamari, Anna A. "Phoenician Women«. A Companion to Euripides. Ur. Laura K. McClure. Chichester: John Wiley \& Sons, 2017. 258-269.

Lloyd-Jones, Hugh. The Justice of Zeus. Berkeley, CA: University of California Press, 1973.

Miola, Robert S. „Early Modern Antigones: Receptions, Refractions, Replays«. Classical Receptions Journal 6.2 (2014): 221-244.

Pindar. Slavospevi in izbrani fragmenti. Prev. Brane Senegačnik. Ljubljana: Družina, 2013.

Pindar. »II. olimpijska oda«. Prev. Jan Ciglenečki. Literatura 21.211/212 (2009): 207214.

Plutarch. Parallel Lives. Volume I. Theseus and Romulus. Lycurgus and Numa. Solon and Publicola (Loeb Classical Library L046). Prev. Bernadotte Perrin. Cambridge, MA: Harvard University Press, 1967.

Scodel, Ruth. "Sophocles' Biography«. A Companion to Sophocles. Ur. Kirk Ormand. Hoboken: Wiley-Blackwell, 2012. 25-37.

Sommerstein, Alan H. "Tragedy and the Epic Cycle». The Greek Epic Cycle and its Ancient Reception. Ur. Marco Fantuzzi in Christos Tsagalis. Cambridge: Cambridge University Press, 2015. 461-486.

Torres-Guerra, José B. »Thebaid«. The Greek Epic Cycle and its Ancient Reception. Ur. Marco Fantuzzi in Christos Tsagalis. Cambridge: Cambridge University Press, 2015. 226-243.

West, Martin L., ur. Greek Epic Fragments (Loeb Classical Library L497). Cambridge, MA: Harvard University Press, 2003.

Zimmermann, Christiane. Der Antigone-Mythos in der antiken Literatur und Kunst. Tübingen: Gunter Narr Verlag, 1993. 


\section{Truly Bewept, Full of Strife: The Myth of Antigone, the Burial of Enemies, and the Ideal of Reconciliation in Ancient Greek Literature}

Keywords: ancient Greek literature / literary myths / Antigone / Homer / Aeschylus / Sophocles / Euripides

Over the past five decades, the myth of Antigone has been the subject of noted literary, literary-critical, dramatic, philosophical, and philological treatments in Slovenia, not least due to the influence of one of the most important Slovenian plays of the twentieth century, Dominik Smole's Antigona. The rich Slovenian discussion of the myth has often dealt with its most famous formulation, the Antigone of Sophocles, but has paid less attention to the broader ancient context; the epic sources (the Iliad, Odyssey, Thebaid, and Oedipodea); the other tragic versions (Aeschylus's Seven Against Thebes and his lost Eleusinians; Euripides's Suppliants, Phoenician Women, and Antigone, of which only a few short fragments have been preserved); and the responses of late antiquity. This article analyses the basic features of this nearly thousand-year ancient tradition and shows how they connect in surprising ways-sometimes even more directly than Sophoclean tragedy does-with the main issues in the Slovenian reception: the question of burying the wartime (or postwar) dead and the ideal of reconciliation.

1.01 Izvirni znanstveni članek / Original scientific article

UDK 821.14'02.09

D0I: https://doi.org/10.3986/pkn.v44.i2.05 